\title{
Environmental Footprints of Economic Development, Foreign Investment, Tourism, and Electricity Production: Empirical Evidence from GCC Region
}

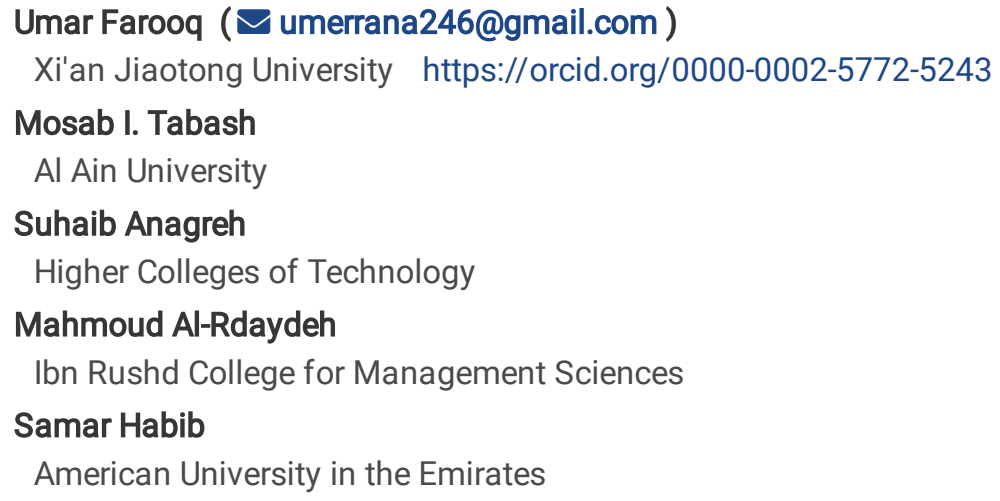

Research Article

Keywords: CO2 Emissions, Economic Development, Pollution Haven Hypothesis, GCC region, Tourism

Posted Date: March 7th, 2022

DOl: https://doi.org/10.21203/rs.3.rs-1334161/v1

License: () (1) This work is licensed under a Creative Commons Attribution 4.0 International License. Read Full License 


\section{Abstract}

Each economic factor generates both positive and negative externalities regarding environmental quality. Owing to this, the current study explores the impacts of various economic factors on the environmental quality of GCC region. By sampling the 24-years (19962019) financial statistics of six GCC region countries, we investigate the impact of economic development, foreign investment, trade volume, tourism investment and revenue, and electricity production etc., on $\mathrm{CO} 2$ emissions. The empirical analysis is based upon FMOLS (fully modified ordinary least square) model due to existence of cointegration. Following the results, economic development, foreign investment, tourism investment, electricity production, and population density have positive while trade volume and banking development have negative impact on volume of $\mathrm{CO} 2$ emissions. The results support the pollution haven hypothesis in GCC region and have many policies for environmental economists regarding the protection of natural environment both in short and long-run. The current analysis offers new insights regarding the dynamic role of various economic factors in establishing the $\mathrm{CO} 2$ emission volume in GCC region.

\section{Introduction}

In 2015, the General Assembly of United Nations argued the famous 17 goals regarding sustainable development. These goals are projected to be accomplished by the year 2030 (UNGA, 2015). Being consider the importance of these goals, the literature has paid much attention on exploration of these goals. Among the others, the literature on sustainable economic growth and the impact of various economic factors on environmental sustainability have gained significant attentions of researchers (Eyuboglu and Uzar, 2020; Huang, et al., 2022). For the time being, each country is concerned about the preservation of natural resources for their future generation. The intensive increment in multiple environment issues has created the serious threats not only for the health of human beings but also other creatures in ocean and air. In the case of GCC, these economies are suffering with intensive climate changes due to sole dependency on fossils fuels as an energy source. According to statistics provided by The World Bank, the four economies of GCC including Bahrain, Oman, Kuwait, and Qatar are 100\% relying on non-renewable energy sources. The ratio in other two economies is not less than $80 \%$. Meanwhile, these economies are experiencing the major inflow of FDI during last few decades. Additionally, the GCC region is considered as one the major tourism destination in the world (Chen, et al., 2018). For instance, Saudi Arabia welcomes the millions Muslim pilgrims on Hajj. All these factors substantially impinge upon the climate quality in this region. Therefore, the current study aims to explore the environmental footprints of various economic factors in this region.

Although the development in economic status, foreign investment, and expansion in other economic activities are always endorsed much focus, the sustainability of natural environment is another agenda that should be adopted by policy officials (Charfeddinea and Kahia, 2019). The stimulus behind the staggering focus on environmental sustainability is extensive increment in environmental issues. The exploration of various economic operations by the economic agents has created a panel of environmental issues e.g., distortion of ozone layer, enrichment of harmful gasses in air, and other health issues. Such environmental degradation shows the incompetency of environmental policies and exploitation of natural resources for personal benefits by the economic agents. Meanwhile, a country may adopt some policy relaxation in environmental compliance in order to achieve the various objectives regarding the rapid economic growth and encouraging the domestic industrial zones on more production (Odhiambo, 2016). However, it becomes necessary to regularize such operations and impose some policy restriction to undermine the environmental degradation. From the real world, the China has made a double-digit economic growth in last decade. Parallelly, it has also faced the extensive increment in $\mathrm{CO} 2$ emissions during this era (Chen, et al., 2018). This phenomenon exemplifies the direct impact of various economic factors on $\mathrm{CO} 2$ emissions and urge to investigate the similar trend in GCC region.

In the viewpoint of above discussion, the current study explores the impact of economic development, foreign investment, trade volume, tourism investment and revenue, and electricity production on environmental quality of GCC region. The empirical analysis is based upon 24-years (1996-2019) statistical scores of six GCC region countries including Bahrain, Kuwait, Oman, Qatar, Saudi Arabia, and United Arab Emirates. To test the underlying theoretical framework, we employ the FMOLS tests due to existence of cointegration and nature of data (macro-panel). The statistical results reveal that economic development, foreign investment, tourism investment, electricity production, and population density are the significant determinants that are boosting the $\mathrm{CO} 2$ emissions in this region. However, a declining trend in $\mathrm{CO} 2$ emissions was observed due to trade volume and financial development. Both factors mitigate the $\mathrm{CO} 2$ emissions in this region. The empirical results robust the findings of previous literature and suggest the existence of pollution haven hypothesis in GCC region. 
The importance of current analysis can be categorized theoretically, empirically, and practically. Theoretically, the current study expands the existing literature by exploring the impact of various economic factors that were argued by the previous studies on $\mathrm{CO} 2$ emissions in the GCC region. It combines the various strands of literature and offers robust theoretical insights for the GCC region. Empirically, the current analysis investigates the impact of the most discussed economic factors on $\mathrm{CO} 2$ emissions and provides empirical support for the stratification of the pollution haven hypothesis in this region. Our study supplements the empirical evidence on both the declining and boosting role of $\mathrm{CO} 2$ emissions in the GCC region. Practically, this study suggests direct policies regarding environmental sustainability in this region. Policy officials should focus on sustainable economic progress, introduce some regulations for foreign investors, and develop policies for alternative energy sources. Meanwhile, they should enhance the banking development and trade volume.

The remaining paper is distributed into 5 sections i.e., section 2 presents the review of literature, section 3 data and methodology, and section 4 demonstrates the empirical results. In section 5 , we discuss the results and conclude the whole study in section 6 . The references are offered at the end of the paper.

\section{Literature Review}

It is eminent that lethal gasses are mandatory to hold the temperature of the earth at some certain level to maintain life. However, huge amounts of such gasses due to man-made operations e.g., extensive use of fossil fuels and other greenhouse gasses bring scorching temperatures and global warming which change the global warming system. Some empirical studies in early $1990 \mathrm{~s}$ independently examined the connection between per capita income and ecological degradation (Panayotou 1993). Their findings further asserted that ecological degradation and per capita income unveiled an upturned U-shaped curve, identified as Ecological Kuznets Curve (EKC). The EG has a direct link with CO2 emission (CE) in the long orientation (Grossman and Krueger 1995; Mikayilov, et al., 2018). Over the previous eras, researchers of environment and economics had been examined with the focus to rocketing EG and mitigate on social dilapidation, as a concern lethal gasses from economic growth. This peculiarity has observed numerous empirical studies assumed primarily to scrutinize the causative link between EG and CE, and to examine the hypothesis for EKC, and thus create appliances of achieving green growth and sustainable economic progression. The EG does not influence by CE for nonOECD allies, but they acquired statistical outcomes that economic development indicates an increment in CE (Dinda, 2009; Odhiambo, 2016). Moreover, there is no significant causal connection between CE and EG and thereby confirmed the impartiality of the hypothesis (Richmond and Kaufmann, 2006).

The FDI dynamic encourages economic development. However, it affects the atmosphere in host economies. Huang, et al., (2022) expressed that cross-border inflow tends to raise the $\mathrm{CO} 2$ emissions (CE) which exhibits a straight link between FDI and CE. But economic development and regulatory quality avert this positive link into negative. We observed a growing literature on linking FDI and CE while reviewing prior literature. However, this link has got eminent rank in the discussions of scholars for the last few decades. Numerous research has inspected the straight impacts of FDI invasions on $\mathrm{CO} 2$ releasing and proposed pollution haven hypothesis, which advocates that invasion of cross border investment led to greater CE. Mostly, the advanced regions prefer to choose developing regions for investment portfolios due to minimum stringent regulations which invite higher CE (Mahadevan and Sun, 2020; Aller, et al., 2021). The amount CE increases due to the enlargement of FDI-led economic operations (Grimes and Kentor, 2003). Grimes and Kentor, (2003) proposed that cross-border invasions significantly upturn CE in less developed regions. Cole, et al., (2006) asserted that high corruption perceptions index countries enhance their CE due to lax ecological strategies.

Tourism is the utmost and mounting industry in the world. The swift advancement of the tourism industry and increasing tourism (TR) mobility has backed significantly to both developed and developing regions. Eyuboglu and Uzar, (2020) asserted that tourism, economic advancement, and energy ingesting affect emissions of $\mathrm{CO} 2$ positively both in short and long orientation. Chen, et al., (2018) established the contact amongst, CE and economic advancement in China. They highlighted that tourism advancement is positively affects CE and specifically the transportation zone is the fundamental cause of CE. Raza, et al., (2017) confirmed the associations of TR with CE in the US during 1997- 2016. The findings' declared TR is a determinant of CE. He, et al., (2019) found that the tourism industry's consumptions are lesser than other industries. Dogan, et al., (2015) exhibited that tourism shrinks ecological quality by increasing emissions of $\mathrm{CO} 2$. The outcomes regarding causality strategy represented the occurrence of a unidirectional causative liaison from TR to CE. Moreover, Shakouri, et al., (2017) confirmed the links among economic advancement, TR, and CE during 1996-2014 in certain Asia-Pacific economies. They pinpointed that tripper invasions directly lead CE in the long orientation. Azam, et al., (2018) investigated the link between TR and CE, specified that tourism positively leads to CO2 emission. 
Akadiri, et al., (2018) evaluated the link among TR, economic advancement, and CE during 1995-2014. Their findings suggested that tourism key determinant of CE. Shi, et al., (2019) evaluated the interconnection between tripper invasions, TR expenses, and CE throughout 1995-2015. The outcomes indicated that tourism overheads enlarge CE in below-average income economies, while tourism invasions have a direct effect on CE both in under and above-average income economies.

Non-renewable energy (NRE) somehow increases CO2 emissions (CE). Various scholars noticed a direct association of NRE with CO2 emissions which reveals that high consumption of NRE leads to CO2 emissions (Awodumi and Adewuyi, 2020). Moreover, Jalil and Feridun, (2011) explored the long-oriented impact of advancement in the financial sector and energy consumption on ecological degradation in China throughout 1954-2007. Their outcomes exposed that aggregate energy consumption has a direct effect on ecological pollution. Acaravci and Ozturk, (2010) Jayanthakumaran, et al., (2012), Ozturk and Acaravci, (2013) also recommended a positive link between NRE and CE for India, China, Europe, Indonesia, and Turkey respectively. Bélaïd and Youssef, (2017) and (Alola, et al., 2019) established that energy consumption is positively associated with ecological pollution. Shahbaz, et al., (2013) have declared that trade openness and financial development have a positive link with CO2 emissions. However, Jalil and Feridun, (2011) disclosed a significant positive contribution to mitigating ecological pollution, but they at the same time stated the positive impact of trade openness with CE. Though, this result is consistent with (Acaravci and Ozturk, 2010; Jayanthakumaran, et al., 2012; Ozturk and Acaravci, 2013).

More than 50 percent population of the entire world lives in urban areas and by 2030 , this ratio will reach 60 percent. In some specific states, 70 percent in Europe is forecasted to be surpassed 80 percent by 2050. This demographic upsurge in urban areas leads to 80 percent of energy being consumed in them. The greater population density augments individual energy consumption (Jorgenson and Clark, 2010; Periñán, et al., 2021). In brief, an increase in population density enlarges CO2 emissions (CE). A mounting of scientific research regarding climate fluctuations causes and consequences has assured instantaneous and continuous reductions in $\mathrm{CO} 2$ emissions (CE) (Lamb, et al., 2014). The interstate quorum on climate disparity (IPCC, 2015) 5th valuation report discloses that CO2 emissions have the main causative of total lethal gas secretion. Growth in population density (PD) for future few years could affect consumption of energy and emissions of CO2, (Hossain, 2011; Liddle, 2015) which unveils that PD has a direct liaison with CE. India has achieved 2nd most populated country in the world and the world's 3rd leading $\mathrm{CO} 2$ emitter with a portion of 5.98 percent to aggregate global emissions in 2010 except the U.S. and China (WDI, 2015). The emissions of lethal gasses increase with an increment in population which exhibits a positive association between PD and CE (Babu \& Kaechele, 2015).

Among others, the development and advancement through contemporary approaches in the financial sector led to economic growth (EG). Moreover, financial development (FD) stimulates economic growth (Charfeddinea \& Kahia, 2019). Their study also recommended a straight link between FD and CO2 emissions (CE). Presently, FD considers indispensable support for EG because it offers an assortment of funds through savings and enlightens the obligatory information regarding investment operations. The FD plays a mandatory role in observing CE by bringing technological advancement in the energy supply sector for mitigating the degree of CE (Jensen, 1996; Shi, 2003). This expresses that FD represents real accessibility of financial resources for productive operations and funding networks for ventures by banks and stock markets (Sadorsky, 2010). The financial development wanes CO2 emissions through CSR and eco-friendly strategies. From this viewpoint, environmental dilapidation lessens with financial advancement. In addition, it boosts research and development (R\&D) efforts, fascinates FDI, and uninterruptedly upsurge economic operations to inspire the ecological quality due to investments in green-associated ventures (Charfeddine, et al., 2018; Hayat, et al., 2018). FD shrinks the leverage acquiring cost which attracts investment operations and stems the scatterings of lethal gasses by enhancing the efficiency of the energy sector (Tamazian and Rao, 2010). Thus, FD may wane the ecological deterioration by boosting industrial operations which obstruct the green atmosphere (Jensen, 1996). Their results support a direct association between financial development and $\mathrm{CO} 2$ emissions.

\section{Data And Methods}

\subsection{Data, Sample, and Variables}

The current empirical analysis is based upon the balanced panel data of 6 GCC region countries (Bahrain, Kuwait, Oman, Qatar, Saudi Arabia, United Arab Emirates). The sampling period is 1996 to 2019. The statistical information of under-consideration variables was extracted from the WDI (world development indicators), The World Bank. The impetus behind the selection of the GCC region is an extensive exploration of non-renewable energy that is causing numerous environmental issues (Al-mulali \& Tang, 2013). Similarly, the 
selection of span is based upon data availability and consistent change in underlying economic situations e.., economic development, FDI inflow, energy dependency, etc., during this era. The current study responds to the research question of how various economic factors including economic development, foreign investment, trade volume, tourism investment and revenue, electricity production, etc., influence the environmental quality in the GCC region. In addition, the existing empirical analysis considers other variables e.g., population density and banking development as control variables. To assess the environmental quality, we use the proxy of $\mathrm{CO} 2$ emissions which is a metric ton per capita emission of $\mathrm{CO} 2$. This proxy illustrates the net exhaust of $\mathrm{CO} 2$ into the air by main $\mathrm{CO} 2$ emitters. It further shows the impact of other economic operations on environmental quality. A range of studies has specified a similar measurement of $\mathrm{CO} 2$ emissions (Charfeddine \& Kahia, 2019). Economic development, foreign investment, trade volume, tourism investment, tourism revenue, and electricity production serve as explanatory variables.

For measurement, we use the annual \% GDP growth for economic development, FDI inflow for foreign investment, and a sum of exports and imports for the measurement of trade volume. Similarly, expenditures on the facilitation of tourism activities and the development of tourist points were used as a proxy of tourism investment. Tourism revenue is a net receipt of income from tourism and scaled as \% of total exports. Electricity production was proxied by the production of electricity from the primary sources of energy in this region i.e., non-renewable energy sources including coal, gas, and oil. For the measurement of control variables, the people resided on per square kilometer area of land were used as a proxy of population density and the proxy variable for banking development is the volume of domestic credit (\% of GDP) extended by private sector banks. The measurement of these variables is based upon the WDI, The World Bank. Additionally, some recent studies have also recommended a similar measurement of these variables (Ameer \& Munir, 2020; Gao, et al., 2021; Farooq, 2022). Table 1 presents the brief description of variables.

Table 1

Variables

\begin{tabular}{|c|c|c|c|}
\hline Variable & Role & Measurement & References \\
\hline CO2 emissions & Dependent & Metric tons/capita & $\begin{array}{l}\text { (Charfeddine \& Kahia, 2019; Gao, et } \\
\text { al., 2021) }\end{array}$ \\
\hline $\begin{array}{l}\text { Economic } \\
\text { development }\end{array}$ & Independent & GDP growth rate & (Ameer \& Munir, 2020) \\
\hline Foreign Investment & Independent & FDI inflow (\% of GDP) & (Luo, et al., 2021) \\
\hline Trade volume & Independent & (Exports + Imports) \% of GDP & (Shahbaz, et al., 2013) \\
\hline $\begin{array}{l}\text { Tourism } \\
\text { Investment }\end{array}$ & Independent & $\begin{array}{l}\text { International tourism, expenditures (\% of total } \\
\text { imports) }\end{array}$ & (Paramati, et al., 2018) \\
\hline Tourism Revenue & Independent & International tourism, receipts (\% of total exports) & (Paramati, et al., 2018) \\
\hline $\begin{array}{l}\text { Electricity } \\
\text { Production }\end{array}$ & Independent & $\begin{array}{l}\text { Electricity production from oil, gas and coal } \\
\text { sources (\% of total) }\end{array}$ & (Bakay \& Ağbulut, 2021) \\
\hline Population density & Independent & Population density (people per sq. km of land area) & (Rahman \& Alam, 2021) \\
\hline $\begin{array}{l}\text { Banking } \\
\text { Development }\end{array}$ & Independent & $\begin{array}{l}\text { Domestic credit to private sector by banks (\% of } \\
\text { GDP) }\end{array}$ & (Acheampong, 2019) \\
\hline
\end{tabular}

\subsection{Equations and Estimation Technique}

To present the underlying theoretical framework for current study, we develop the following equation.

$$
C O 2_{i t}=\beta_{\circ}+\alpha_{1} E D_{i t}+\alpha_{2} F D I_{i t}+\alpha_{3} T D V_{i t}+\alpha_{4} T R I_{i t}+\alpha_{5} T R R_{i t}+\alpha_{6} E P R_{i t}+\gamma_{1} P O D_{i t}+\gamma_{2} D C B_{i t}+\mu_{i}+\omega_{t}+\epsilon_{i t} e q .
$$

In Eq. (1), CO2 is a vector of CO2 emissions, ED is economic development, FDI is FDI inflow, TDV is trade volume, TRI is tourism investment, TRR is tourism revenue, and EPR shows the electricity production. Similarly, POD is an acronym of population density, and DCD shows the banking development. Other symbols e.g., $\beta$ 。 is a constant, showing the intercept while $a$ and $y$ are the coefficients of explanatory variables. Similarly, $\mu_{i}$ is for country and $\omega_{t}$ is an indication of time fixed effect. The subscripts $i, t$ represent variation of countries and time respectively while $\epsilon_{i t}$ denotes the residual term. 
As the analysis contains many macroeconomic variables, therefore it is necessary to check the stationarity of data. For this purpose, the current study employs the unit root testing and considers the results of the ADF test (Dickey \& Fuller, 1979), and Im, Pesaran, and Shin test (Im, et al., 2003) to unveil the stationarity status. The statistical analysis shown in Table 3 demonstrates the stationarity of most variables at level 1 . This non-stationary status of variables at a level further motivates to check the integration among the variables. We test the long-run cointegration among the variables by employing the Johansen cointegration test proposed by Johansen (1988) and select the Kao-residual cointegration. This test produces more reliable results as it can detect the cointegration even when there is more than one explanatory variable. Additionally, it tests all the series in the long run and produces unbiased analysis (Ozturk, et al., 2021). The significant p-values $(p \leq 0.05)$ of the Kao-residual test affirms the alternative hypothesis i.e., there exists cointegration among the variables.

Owing to existence of cointegration, the current analysis mainly considers the fully modified ordinary least square (FMOLS) tests to investigate the regression among the variables. FMOLS model was first formulated by Phillips \& Hansen, (1990) to estimate the coefficients in the long run. Additionally, this model is more appropriate in macro-panel analysis $(\mathrm{N}<\mathrm{T})$ and has the capacity to resolve the potential issue of endogeneity observed in explanatory variables. FMOLS model is effective in order to eliminate the successive problem of high correlations and overlapping of the error terms. All these assumptions support the implication of the FMOLS test in the current case. The contemporary literature has also utilized the FMOLS model to investigate the regression analysis (Wen, et al., 2021; Ozturk, et al., 2021; Farooq, 2022).

\section{Empirical Results}

\subsection{Descriptive Analysis}

Table 2 presents the overall descriptive analysis for the variables of study while Table 3 demonstrates the mean trends of main variables across the under-analysis countries. Concentrating on statistics shown in Table 3, Qatar has the highest CO2 emission value of 36.820, illustrating the worst environmental quality in Qatar. Comparably, the economic growth in Qatar is 8.258 which is the highest compared to other companion countries. Bahrain is experiencing the highest FDI inflow of $5.621 \%$ of its total GDP. As likely to FDI, Bahrain also has the highest volume of trade 146.707. However, Kuwait is making the highest tourism investment of 22.779 while the highest tourism revenue is earned by Bahrain which is $11.771 \%$ of its total exports. In most GCC region countries (Bahrain, Kuwait, Oman, and Qatar), non-renewable energy sources are the only sources for producing electricity. The highest population density value is 157.387 which is owned by Kuwait. Lastly, the highest banking sector development score is 65.530 which is earned by Kuwait.

Table 2

Descriptive Results

\begin{tabular}{|lllllll|}
\hline & Mean & Median & Std. dev. & Maximum & Minimum & observations \\
\hline CO2 & 22.471 & 21.821 & 0.054 & 47.699 & 7.071 & 144 \\
\hline ED & 4.397 & 3.724 & 0.073 & 26.170 & -7.076 & 144 \\
\hline FDI & 2.506 & 1.528 & 0.078 & 33.566 & -3.175 & 144 \\
\hline TDV & 106.534 & 96.324 & 0.158 & 191.876 & 56.088 & 144 \\
\hline TRI & 12.481 & 9.561 & 0.064 & 28.717 & 2.855 & 144 \\
\hline TRR & 5.066 & 3.160 & 0.138 & 18.493 & 0.507 & 144 \\
\hline EPR & 96.232 & 100.000 & 0.081 & 100.000 & 67.673 & 144 \\
\hline POD & 299.429 & 93.699 & 0.091 & 2104.056 & 7.226 & 144 \\
\hline DCB & 51.343 & 45.858 & 0.083 & 105.187 & 20.792 & 144 \\
\hline
\end{tabular}

Acronym's detail: $C O 2=C O 2$ emissions, $E D=$ economic development,$F D I=F D I$ inflow, $T D V$, trade volume, $T R I=$ tourism investment, $T R R=$ tourism revenue, $E P R=$ electricity production, $P O D=$ population density, $D C B=$ domestic credit by banks Source: own calculation. 
Table 3

Mean Trend across the Countries

\begin{tabular}{|lllllll|}
\hline & Bahrain & Kuwait & Oman & Qatar & Saudi Arabia & U.A.E. \\
\hline CO2 & 22.322 & 24.377 & 13.133 & 36.820 & 14.296 & 23.875 \\
\hline ED & 4.393 & 3.165 & 3.224 & 8.258 & 3.027 & 4.314 \\
\hline FDI & 5.621 & 0.408 & 2.282 & 2.372 & 1.996 & 2.357 \\
\hline TDV & 146.707 & 93.280 & 102.650 & 91.913 & 74.050 & 130.603 \\
\hline TRI & 7.959 & 22.779 & 7.189 & 19.045 & 8.533 & 9.378 \\
\hline TRR & 11.771 & 1.374 & 4.448 & 5.755 & 3.445 & 3.578 \\
\hline EPR & 100 & 100 & 100 & 100 & 77.466 & 99.929 \\
\hline POD & 1397.462 & 157.387 & 10.083 & 130.173 & 12.109 & 89.360 \\
\hline DCB & 57.822 & 65.530 & 45.989 & 46.122 & 37.512 & 55.081 \\
\hline
\end{tabular}

Acronym's detail: $C O 2=C O 2$ emissions, $E D=$ economic development,$F D I=F D I$ inflow, $T D V$, trade volume, $T R I=$ tourism investment, $T R R=$ tourism revenue, $E P R=$ electricity production, $P O D=$ population density, $D C B=$ domestic credit by banks Source: own calculation

\subsection{Correlation Analysis}

Table 4 is presenting the correlation statistics among the variables. Most correlation statistics are less than 0.70 , rejecting the existence of multicollinearity issue. Excluding TDV, column 2 shows that all variables have positive correlation statistics with $\mathrm{CO} 2$, implying the direct correlation between $\mathrm{CO} 2$ emissions and other variables of study.

Table 4

Correlation Results

\begin{tabular}{|c|c|c|c|c|c|c|c|c|c|}
\hline & $\mathrm{CO} 2$ & ED & FDI & TDV & TRI & TRR & EPR & POD & DCB \\
\hline $\mathrm{CO} 2$ & 1.000 & & & & & & & & \\
\hline ED & 0.418 & 1.000 & & & & & & & \\
\hline FDI & 0.063 & 0.188 & 1.000 & & & & & & \\
\hline TDV & -0.008 & -0.011 & 0.381 & 1.000 & & & & & \\
\hline TRI & 0.550 & 0.099 & -0.262 & -0.284 & 1.000 & & & & \\
\hline TRR & 0.038 & -0.075 & 0.183 & 0.313 & -0.226 & 1.000 & & & \\
\hline EPR & 0.412 & 0.138 & 0.063 & 0.466 & 0.268 & 0.182 & 1.000 & & \\
\hline POD & 0.035 & -0.014 & 0.240 & 0.606 & -0.181 & 0.632 & 0.235 & 1.000 & \\
\hline DCB & 0.016 & -0.312 & -0.106 & 0.429 & 0.296 & 0.232 & 0.323 & 0.309 & 1.000 \\
\hline
\end{tabular}

\subsection{Panel Regression Results}

Prior to analyzing the regression, we test the stationarity of variables by employing the unit root testing and report the results in Table 5. The statistical outcomes imply that most variables show the stationarity status at level 1 , claiming to investigate the cointegration in the long run. To identify the cointegration, we explore the Johnsen cointegration test and choose Kao Residual test (analysis is shown in Table 6). The significant probability value of this test rejects the null hypothesis i.e., no cointegration exists. The existence of cointegration tests signifies the implication of the FMOLS test for testing Eq. 1. As the analysis is shown in Table 7, economic development has a significant coefficient value of 1.104, illustrating that a one-unit increase in economic development can 
enhance the $\mathrm{CO} 2$ emissions by $1.104 \%$. The coefficient value of the foreign investment is 1.494 , implying the positive contribution of foreign investment in $\mathrm{CO} 2$ emissions. Nonetheless, trade volume has a negative coefficient value of -0.584 , indicating that trade volume can reduce environmental degradation. Tourism investment has a positive significant adherence while tourism revenue has an insignificant association with $\mathrm{CO} 2$ emissions. Other factors e.g., electricity production and population density positively while banking development negatively contribute to the $\mathrm{CO} 2$ emissions volume in the GCC region.

Table 5

Unit Root Testing

\begin{tabular}{|lllll|}
\hline & \multicolumn{2}{c}{ Im, Pesaran and Shin W-stat } & \multicolumn{2}{l|}{ ADF - Fisher Chi-square } \\
\hline Variables & Statistics & Probability & Statistics & Probability \\
\hline CO2 Emissions (-1) & -3.817 & 0.000 & 36.502 & 0.000 \\
\hline Economic development & -3.076 & 0.000 & 31.957 & 0.001 \\
\hline FDI inflow (-1) & -5.277 & 0.000 & 49.950 & 0.000 \\
\hline Trade volume & -1.277 & 0.090 & 19.512 & 0.084 \\
\hline Tourism investment (-1) & -11.936 & 0.002 & 3.2 .404 & 0.000 \\
\hline Tourism revenue (-1) & -6.570 & 0.000 & 62.928 & 0.000 \\
\hline Electricity production (-1) & -1.948 & 0.025 & 11.183 & 0.000 \\
\hline Population density & -2.907 & 0.003 & 35.279 & 0.000 \\
\hline Banking development (-1) & -5.546 & 0.000 & 52.545 & 0.000 \\
\hline Note: most variables are stationary at level 1. Source: self-estimation. & \\
\hline
\end{tabular}

Table 6

Cointegration Diagnostic

\begin{tabular}{|lll|}
\hline Kao Residual Cointegration Test & & \\
\hline Test name & t-statistics & Probability \\
\hline ADF & -1.993 & 0.023 \\
\hline Residual variance & 1.794 & - \\
\hline HAC variance & 1.947 & - \\
\hline Note: The significant value of ADF rejects Ho: i.e., No cointegration. Source: self-estimation \\
\hline
\end{tabular}


Table 7

Regression Analysis

\begin{tabular}{|c|c|c|c|c|}
\hline & \multicolumn{4}{|c|}{ Dependent variable $=\mathrm{CO} 2$ emissions } \\
\hline & \multicolumn{2}{|l|}{ Fixed effect } & \multicolumn{2}{|l|}{ FMOLS } \\
\hline & Coefficient & Probability & Coefficient & Probability \\
\hline Constant & 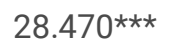 & 0.001 & - & - \\
\hline Economic development & $0.156^{\star \star \star}$ & 0.008 & $1.104 * \star \star$ & 0.009 \\
\hline FDI inflow & $0.149 * \star$ & 0.060 & $1.494^{\star \star}$ & 0.064 \\
\hline Trade volume & $-0.078 * \star \star$ & 0.000 & $-0.584^{\star \star \star}$ & 0.004 \\
\hline Tourism investment & -0.093 & 0.329 & $0.573^{*}$ & 0.090 \\
\hline Tourism revenue & $-0.281 * \star \star$ & 0.008 & -1.113 & 0.253 \\
\hline Electricity production & $0.034 * \star$ & 0.070 & $0.248 * \star \star$ & 0.044 \\
\hline Population density & $-0.003^{\star \star \star}$ & 0.044 & $0.274^{\star}$ & 0.109 \\
\hline Banking development & 0.030 & 0.181 & $-0.304 \star \star$ & 0.089 \\
\hline Adjusted R-squared & 0.889 & & 0.327 & \\
\hline S.E of regression & 0.089 & & 0.053 & \\
\hline Prob (F-statistics) & 0.000 & & - & \\
\hline Long-run variance & - & & 45.343 & \\
\hline
\end{tabular}

\section{Discussion}

The current analysis probes the influence of various macroeconomic factors on the environmental quality of GCC region countries. For empirical assessment, we employ the FMOLS test and mentioned the results in Table 7. As the coefficient values prevail, the economic development has a direct impact on $\mathrm{CO} 2$ emissions, signifying the deteriorating role of economic development in environmental quality. For quick economic development, the different activities e.g., production and consumption of pollutionintensive products are performed at a massive level. This factor causes environmental degradation. Additionally, the propagation of economic growth requires the massive production of various products by industrial units and hence causes environmental degradation (Ameer \& Munir, 2020). The overall economic growth reflects the consistent increment in net domestic products that enhance the exhaust of $\mathrm{CO} 2$ emissions. Supporting this, the study of Ozturk, et al., (2021) inferred similar results in the GCC region. FDI inflow positively influences the volume of $\mathrm{CO} 2$ emissions, corroborating the underlying assumptions of the pollution haven hypothesis in this region. This theory claims that the inflow of foreign investment boosts the production of such particles that impede the environmental quality. The exploration of foreign investment enhances the pace of industrial establishments, extensive economic activities, and disregarding the environmental sustainability by foreign investors (Farooq, 2022). Foreign investors are interested in enhancing the profit volume by leaps and bounds and mostly ignore environmental sustainability due to the occurrence of extra costs for compliance with environmental protection. Additionally, they also enjoy the relaxation in environmental regulations by local governments and hence undermine the activities regarding the preservation of the natural environment (Luo, et al., 2021). All these factors substantially lead to environmental degradation.

Trade volume has a negative coefficient, indicating the favorable impacts of trade volume on environmental quality. Unlike common literature findings (Ansari, et al., 2020; Essandoh, et al., 2020), this inverse relationship between trade volume and $\mathrm{CO} 2$ emissions can be explained as a higher trade volume allows for the transformation of modern technology and hence reduces the $\mathrm{CO} 2$ emissions. Trade volume also reflects the trade liberalization, incurring the bi-directional sharing of modern production systems and favorable competition (Sbai, et al., 2014). Both factors lead to reduce environmental degradation. This inverse relationship between trade volume and $\mathrm{CO} 2$ emissions stands with the theoretical description of the pollution halo hypothesis. Tourism investment which is an 
expansion and modification in tourists points positively contributes to $\mathrm{CO} 2$ emissions. The development in tourist points attracts more tourists and hence more economic activities incurred in this region which eventually led to extensive emissions of $\mathrm{CO} 2$. The empirical results of the studies conducted by Koçak, et al., (2020), and Ravinthirakumaran and Ravinthirakumaran (2022) aligned with such results. Nonetheless, tourism revenue does not impact CO2 emissions in GCC region.

Continuing the discussion, the production of electricity from non-renewable sources of energy has positive adherence with $\mathrm{CO} 2$ emissions. GCC region is mostly relying on oil, gas, and oil to produce electricity. The combustion of such energy sources substantially enhances the emissions of smoke and other particles that cause environmental degradation. In addition to electricity, the sole dependency of industrial units and the transportation sector on non-renewable energy is continuously reinforcing the degradation of the natural environment in this region. The direct impact of electricity production from non-renewable energy sources on CO2 emissions provides robustness to the empirical findings of Shafiei and Salim (2014) and Zmami and Ben-Salha (2020). Explaining the effect of control variables, both population density and banking development have a positive correlation with $\mathrm{CO} 2$ emissions. The region with more population density necessarily experiences outstanding economic activities e.g., consumption of industrial goods. This factor enhances the emissions of $\mathrm{CO} 2$ in this region. Additionally, higher population density reflects the more burden on natural resources e.g., water, air, and other consumable goods which eventually results in impeding the level of such resources and hence causes more emissions of $\mathrm{CO} 2$ (Zmami \& Ben-Salha, 2020). Lastly, the negative association of financial development with $\mathrm{CO} 2$ emissions is claiming that the development of the financial sector can enhance the pace of technological development and thus significantly reduces environmental degradation. The development status of the banking sector allows the industrial sectors to adopt the modern production systems, import updated technology, and low-cost financing for eliminating the operations causing high environmental deteriorations. In coalition, all these factors reduce the emissions of $\mathrm{CO} 2$. A list of studies has asserted the similar role of financial development in mitigating environmental deterioration (Shahbaz, et al., 2013; Charfeddine \& Kahia, 2019; Lv \& Li, 2021).

\section{Conclusion And Policies}

The current analysis is an attempt to explore the environmental footprints of various economic factors including economic development, foreign investment, trade volume, tourism revenue and investment, electricity production, etc., in the GCC region. To estimate the regression, we mainly use the FMOLS tests and check the effect of economic factors in the long run. The statistical results imply that economic development, foreign investment, tourism investment, electricity production, and population density have a positive impact on environmental degradation. The adverse impact of foreign investment on environmental quality confirms the pollution haven hypothesis in this region. Economic development induces $\mathrm{CO} 2$ emissions due to increments in economic activities. Similarly, the foreign investment makes the domestic market a pollution haven by exploration of more industrial units and disregarding environmental sustainability. Tourism investment enhances the economic activities in the region, resulting in excessive consumption of goods which further produces more $\mathrm{CO}$. The positive impact of the production of electricity from fossils fuels can be regarded as it creates numerous negative externalities in the form of smoke and combustion of pollution-intensive sources. Similarly, population density deteriorates the environmental quality by inducing more pressure on natural resources. Nonetheless, the empirical analysis argued the negative impact of trade volume and financial development on $\mathrm{CO} 2$ emissions in GCC region countries. Both factors can mitigate the volume of $\mathrm{CO} 2$ by boosting the knowledge transformation and availability of funds to explore the pollution mitigation activities.

From the underlying relationship of various economic factors with $\mathrm{CO} 2$ emissions, the following policies can be recommended. In parallel to economic development, the policy officials from the GCC region should focus on environmental sustainability. They should exert more effort for developing sustainable economic growth policies. Similarly, they should introduce some regulations e.g., green productivity, and environmental tax for foreign investors in order to reduce the volume of $\mathrm{CO} 2$ emissions. It is further recommended to policy economists in the GCC region that they should enhance the trade volume and development of the banking sector. Both factors can mitigate the $\mathrm{CO} 2$ emissions. More specifically, energy economists in the GCC region should immediately develop policies that transform the energy dependency from non-renewable to renewable energy sources. It looks that the extensive combustion of fossil fuels is a primary source of environmental degradation in this region as most economies are producing $100 \%$ energy from such sources (follow statistics in Table 3).

The current study has a limitation as it considers all GCC economies in a panel and check underlying relationships combinedly. Each country might have a separate trend. Despite this limitation, the empirical analysis extends the existing literature and provides

Page $10 / 14$ 
multiple policies. Future studies can be arranged by following the assumptions of the famous Environmental Kuznets Curve (EKC) hypothesis in this region.

\section{Declarations}

\section{Ethical Approval}

I (Umar Farooq) hereby confirmed that paper is solely submitted to this journal and not under the publication process in any other journal.

\section{Consent to Participate}

In this research, no human being/Animals involved in direct research or observation. Analysis purely based upon secondary data available on different data sites.

\section{Consent to Publish}

We hereby grant the consent and acknowledge that paper should be sent for peer review, or any other publication process required by journal.

\section{Authors Contribution}

Umar Farooq: drafting, funding acquisition, Writing- Original draft preparation, methodology

Mosab I. Tabash: Supervision, Conceptualization, Data curation,

Suhaib Anagreh: Reviewing and Editing, Methodology

Ghaleb A. El Refae: Data curation, Writing- revised draft preparation

Mahmoud Al-Rdaydeh: formal analysis, Conceptualization, Software

Samar Habib: Grammatical correction, Validation, reviewing

\section{Funding Information}

We receive no direct funding for the conduct of this research.

\section{Competing Interest}

I (Umar Farooq), acting as corresponding author hereby declare on the behalf of my co-authors that we have no conflict of interest.

\section{Availability of Data and Materials}

Data that were used in formal analysis do not require any formal consent and can be provided on demand.

\section{References}

1. Akadiri SS, Lasisi TT, Uzuner G, Akadiri AC (2018) Examining the causal impacts of tourism, globalization, economic growth and carbon emissions in tourism island territories: Bootstrap panel Granger causality analysis.Current Issues in Tourism, pp.1-15 
2. Charfeddinea L, Kahia M (2019) Impact of renewable energy consumption and financial development on CO2 emissions and economic growth in the MENA region: A panel vector autoregressive (PVAR) analysis. Renewable Energy 139(1):198-213

3. Lamb WF et al (2014) Transitions in pathways of human development and carbon emissions. Environ Res Lett 9(1):1-10

4. Odhiambo NM (2016) Coal Consumption and Economic Growth in South Africa. Energy and Environment 27(1):215-226

5. Panayotou T (1993) Empirical tests and policy analysis of environmental degradation at different stages of economic development. International Labour Organization, Geneva

6. Acaravci A, Ozturk I (2010) On the relationship between energy consumption, $\mathrm{CO} 2$ emissions and economic growth in Europe. Energy 35(12). p. https://doi.org/10.1016/j.energy.2010.07.009

7. Acheampong AO (2019) Modelling for insight: Does financial development improve environmental quality? Energy Econ 83(September):156-179

8. Aller C, Ductor L, Grechyna D (2021) Robust determinants of CO2 emissions. Energy Econ 96(1). p. https://doi.org/10.1016/j.eneco.2021.105154

9. Al-mulali U, Tang CF (2013) Investigating the validity of pollution haven hypothesis in the gulf cooperation council (GCC) countries. Energy Policy 60(September):813-819

10. Alola AA, Bekun FV, Sarkodie SA (2019) Dynamic impact of trade policy, economic growth, fertility rate, renewable and nonrenewable energy consumption on ecological footprint in Europe. Sci Total Environ 685(1):702-709

11. Ameer A, Munir K (2020) Nonlinear effect of FDI, Economic Growth, and Industrialization on Environmental Quality: Evidence from Pakistan. Manage Environ Qual 31(1):223-234

12. Anon (2015) Intergovernmental panel on climate change: the fifth assessment report. IPCC, Gevena

13. Anon (2015) World development indicators 2015, DC. World Bank, Washington

14. Ansari MA, Haider S, Khan NA (2020) Does trade openness affects global carbon dioxide emissions: Evidence from the top CO2 emitters. Manage Environ Qual 31(1):32-53

15. Awodumi OB, Adewuyi AO (2020) The role of non-renewable energy consumption in economic growth and carbon emission: Evidence from oil producing economies in Africa. Energy Strategy Reviews 27(1). p. https://doi.org/10.1016/j.esr.2019.100434

16. Azam M, Alam MM, Hafeez MH (2018) Effect of tourism on environmental pollution: Further evidence from Malaysia, Singapore and Thailand. J Clean Prod 190(1):330-338

17. Babu TA, Kaechele H (2015) Dichotomy in carbon dioxide emissions-the case of India. Climate Dev 7(2):165-174

18. Bakay MS, Ağbulut Ü (2021) Electricity production based forecasting of greenhouse gas emissions in Turkey with deep learning, support vector machine and artificial neural network algorithms. Journal of Cleaner Production, 285(Febraury)

19. Bélaïd F, Youssef M (2017) Environmental degradation, renewable and non-renewable electricity consumption, and economic growth: Assessing the evidence from Algeria. Energy Policy 102(1):277-287

20. Charfeddine L, Al-Malk AY, Korbi K (2018) Is it possible to improve environmental quality without reducing economic growth: Evidence from the Qatar economy. Renew Sustainable Energy Rev 82(1):25-39

21. Charfeddine L, Kahia M (2019) Impact of Renewable Energy Consumption and Financial Development on CO2 Emissions and Economic Growth in the MENA region: A Panel Vector Autoregressive (PVAR) Analysis. Renewable Energy 139(August):198-213

22. Chen L, Thapa B, Yan W (2018) The relationship between tourism, carbon dioxide emissions, and economic growth in the Yangtze River Delta, China. Sustainability, 10(1), pp. 1-20

23. Cole MA, Elliott RJR, Fredriksson PG (2006) Endogenous pollution havens: Does FDI influence environmental regulations? Scandinavian J Econ 108(1):157-178

24. Dickey DA, Fuller WA (1979) Distribution of the Estimators for Autoregressive Time Series With a Unit Root. J Am Stat Assoc 74(366):427-431

25. Dinda S (2009) Climate Change and Human Insecurity. Int J Global Environ 9(1):103-109

26. Dogan E, Seker F, Bulbul S (2015) Investigating the impacts of energy consumption, real GDP, tourism and trade on CO2 emissions by accounting for cross-sectional dependence: A panel study of OECD countries. Curr Issues Tourism 20(16):1-19

27. Essandoh OK, islam M, Kakinaka M (2020) Linking international trade and foreign direct investment to CO2 emissions: Any differences between developed and developing countries?.Science of The Total Environment, Volume 712

Page $12 / 14$ 
28. Eyuboglu K, Uzar U (2020) The impact of tourism on CO2 emission in Turkey. Curr Issues Tourism 23(13):1631-1645

29. Farooq U (2022) Foreign direct investment, foreign aid, and CO2 emissions in Asian economies: does governance matter? Environ Sci Pollut Res 29(5):7532-7547

30. Gao C et al (2021) Decoupling of Provincial Energy-related CO2 Emissions from Economic Growth in China and its Convergence from 1995 to 2017.Journal of Cleaner Production

31. Grimes P, Kentor J (2003) Exporting the greenhouse: foreign capital penetration and CO? Emissions 1980 1996. J World-Syst Res 9(1):261-275

32. Grossman GM, Krueger AB (1995) Economic Growth and the Environment. Q J Econ 110(2):353-377

33. Hayat F, Pirzada MDS, Khan AA (2018) The validation of Granger causality through formulation and use of finance-growthenergy indexes. Renew Sustain Energy Rev 81(1):1859-1867

34. Hossain MS (2011) Panel estimation for CO2 emissions, energy consumption, economic growth, trade openness and urbanization of newly industrialized countries. Energy Policy 39(11):6991-6999

35. Huang $\mathrm{Y}$ et al (2022) The impacts of FDI inflows on carbon emissions: Economic development and regulatory quality as moderators. Front Energy Res 9(1):1-11

36. Im KS, Pesaran MH, Shin Y (2003) Testing for Unit Roots in Heterogeneous Panels. J Econ 115(1):53-74

37. Jalil A, Feridun M (2011) The impact of growth, energy and financial development on the environment in China: A cointegration analysis. Energy Econ 33(2). p. https://doi.org/10.1016/j.eneco.2010.10.003

38. Jayanthakumaran K, Verma R, Liu Y (2012) CO2 emissions, energy consumption, trade and income: A comparative analysis of China and India. Energy Policy 42(1). p. https://doi.org/10.1016/j.enpol.2011.12.010

39. Jensen AL (1996) Beverton and Holt life history invariants result from optimal trade off of reproduction and surviva. Can J Fish Aquat Sci 53(1):820-822

40. Johansen S (1988) Statistical analysis of co-integrating vectors. J Economic Dynamics Control 12(2-3):231-254

41. Jorgenson AK, Clark B (2010) Assessing the temporal stability of the population/environment relationship in comparative perspective: a cross-national panel study of carbon dioxide emissions, 1960-2005. Popul Environ 32(1):27-41

42. Koçak E, Ulucak R, Ulucak Z (2020) The impact of tourism developments on CO2 emissions: An advanced panel data estimation.Tourism Management Perspectives, 33(January)

43. Liddle B (2015) What are the carbon emissions elasticities for income and population? Bridging STIRPAT and EKC via robust heterogeneous panel estimates. Glob Environ Change 31(1):62-73

44. Luo Y, Salman M, Lu Z (2021) Heterogeneous impacts of environmental regulations and foreign direct investment on green innovation across different regions in China. Sci Total Environ 759:1-11

45. Lv Z, Li S (2021) How financial development affects CO2 emissions: A spatial econometric analysis.Journal of Environmental Management, Volume 277

46. Mahadevan R, Sun Y (2020) Effects of foreign direct investment on carbon emissions: Evidence from China and its Belt and Road countries. ournal of Environmental Management 276(1). p. https://doi.org/10.1016/j.jenvman.2020.111321

47. Mikayilov JI, Galeotti M, Hasanov FJ (2018) The impact of economic growth on CO2 emissions in Azerbaijan. J Clean Prod 197(1):1558-1572

48. Ozturk I, Acaravci A (2013) The long-run and causal analysis of energy, growth, openness and financial development on carbon emissions in Turkey. Energy Econ 36(1):262-267

49. Ozturk I, Aslan A, Altinoz B (2021) Investigating the nexus between $\mathrm{CO} 2$ emissions, economic growth, energy consumption and pilgrimage tourism in Saudi Arabia.Economic Research-Ekonomska Istraživanja, pp.1-16

50. Paramati SR, Alam MS, Lau CKM (2018) The effect of tourism investment on tourism development and CO2 emissions: empirical evidence from the EU nations. J Sustainable Tourism 26(9):1587-1607

51. Periñán PJZ, Soto IMZ, Soto FJZ (2021) Influence of Population Density on CO2 Emissions Eliminating the Influence of Climate. Atmosphere 12(19). p. https://doi.org/10.3390/atmos12091193

52. Phillips PC, Hansen BE (1990) Statistical inference in instrumental variable regression with I(1) processes. Rev Econ Stud 57(1):99-125 
53. Rahman MM, Alam K (2021) Clean energy, population density, urbanization and environmental pollution nexus: Evidence from Bangladesh. Renewable Energy 172(July):1063-1072

54. Ravinthirakumaran K, Ravinthirakumaran N (2022) Examining the relationship between tourism and CO2 emissions: evidence from APEC region.Anatolia.

55. Raza SA, Sharif A, Wong WK, Karim MZA (2017) Tourism development and environmental degradation in the United States: Evidence from wavelet-based analysis. Curr Issues Tourism 20(16):1768-1790

56. Richmond AK, Kaufmann RK (2006) Is there a Turning Point in the Relationship Between Income and Energy use and/or Carbon Emissions? Ecol Econ 56(1):176-189

57. Sadorsky P (2010) The impact of financial development on energy consumption in emerging economies. Energy Policy 38(1):2528-2535

58. Sbai R, Shahbaz M, Hamdi H (2014) A contribution of foreign direct investment, clean energy, trade openness, carbon emissions and economic growth to energy demand in UAE. Econ Model 36(C):191-197

59. Shafiei S, Salim RA (2014) Non-renewable and renewable energy consumption and CO2 emissions in OECD countries: A comparative analysis. Energy Policy 66(March):547-556

60. Shahbaz M, Hye QMA, Tiwari AK, Leitão NC (2013) Economic growth, energy consumption, financial development, international trade and CO2 emissions in Indonesia. Renew Sustain Energy Rev 25(September):109-121

61. Shahbaz M, Tiwari AK, Nasir M (2013) The effects of financial development, economic growth, coal consumption and trade openness on CO2 emissions in South Africa. Energy Policy 61(1):1452-1459

62. Shakouri B, Yazdi SK, Ghorchebigi E (2017) Does tourism development promote CO2 emissions? Anatolia 28(3):444-452

63. Shi A (2003) The impact of population pressure on global carbon dioxide emissions, 1975-1996: evidence from pooled crosscountry data. Ecol Econ 44(1):29-42

64. Shi H et al (2019) Global difference in the relationships between tourism, economic growth, CO2 emissions, and primary energy consumption. Curr Issues Tourism 23(9):1-16

65. Tamazian A, Rao BB (2010) Do economic, financial and institutional developments matter for environmental degradation? Evidence from transitional economies. Energy Econ 32(1):137-145

66. United-Nations-General-Assembly-(UNGA) (2015) Sustainable Development Goals. s.n, New York

67. Wen $J$ et al (2021) Governance and tax revenue: does foreign aid matter? International Review of Administrative Sciences

68. Zmami M, Ben-Salha O (2020) An empirical analysis of the determinants of CO2 emissions in GCC countries. Int J Sustainable Dev World Ecol 27(5):469-480 